\title{
Ecos do drama grego no teatro contemporâneo: a Antiguidade Clássica grega vista segundo os paradigmas contemporâneos de gênero, classe e etnia
}

Echoes of the Greek Drama in the Contemporary Theatre: Classical Antiquity from the perspective of contemporary issues of class, gender and ethnicity

Entrevista concedida a Maria Brígida de Miranda pela pesquisadora grega, Anastasia Bakogianni ${ }^{1}$

Tradução

Maria Brígida de Miranda ${ }^{2}$

Transcrição

Arthur Rogoski Gomes (bolsista de I.C.), Dra. Maria Brígida de Miranda e

Silvana Tomie Murahara ${ }^{3}$ (colaboradora contratada).

Entrevista filmada por Miranda, no dia 28 de maio de 2015, em Florianópolis, Santa Catarina, Brasil. 


\section{Resumo}

Nesta entrevista, concedida à Dra. Maria Brígida de Miranda (PPGT/UDESC), Bakogianni aponta como a Antiguidade Clássica tem sido revista segundo paradigmas contemporâneos e discorre, dentre outros assuntos, sobre o impacto revolucionário causado pela entrada de mulheres na área dos Estudos Clássicos - um domínio até então historicamente masculino. Do mesmo modo, a pesquisadora, nascida em Atenas, exemplifica como o teatro contemporâneo em países europeus e africanos reflete os ecos e as dissonâncias entre a Antiguidade Clássica e o Ocidente do século XIX. Além disso, traça uma fascinante reflexão sobre como diretoras e diretores lidam com questões de gênero, classe e etnia, ao retratarem heroínas trágicas em produções teatrais. Interessada em como o teatro brasileiro absorveu os ecos do drama grego, Bakogianni direciona sua atenção para a produção londrina Our Lady of the Drowned 4 (2006), dirigida por Kwong Loke e baseada no texto Nossa Senhora dos Afogados, do dramaturgo brasileiro Nelson Rodrigues. Ao analisar a prática teatral dos dias de hoje, ela reflete sobre como a religiosidade arcaica, força motriz da ação dramática na Antiguidade Clássica, é considerada minimizada ou rechaçada nas produções teatrais contemporâneas.

Palavras-chave: Teatro grego; heroínas trágicas; gênero; Electra; Nelson Rodrigues

\section{Abstract}

Interview with Dr Anastasia Bakogianni, Ph.D. in Classical Studies at the London University, granted to Dr Maria Brígida de Miranda, lecturer at PPGT/UDESC. In this interview Doctor Bakogianni explains how the Classical Antiquity has been reviewed from contemporary paradigms. She talks, amongst other issues, of the revolutionary impact caused by the arrival of women as researchers in the domain of Classical Studies - a historically masculine bastion. Bakogianni exemplifies how the contemporary theatre in European and African countries reflects the echoes and dissonances between the Classical Antiquity and the Occident of the XIX century. Moreover, this Athens-born researcher, draws a fascinating reflection on how female and male directors deal with gender, class and ethnic related matters when portraying tragical heroins in theatrical production. With a keen interest in how Brazilian dramaturgy absorbed echoes of the the Greek Drama, Bakogianni steers her look at the London's production "Our Lady of the Drowned" (2006) directed by Kwong Loke, and based on the like-text original Nossa Senhora dos Afogados, by the Brazilian dramaturgist Nelson Rodrigues. In analyzing the theatrical practice of current days, Bakogianni reflects on how the Archaic religiosity, the engine of dramatic art in classical Antiquity is considered, minimized or repelled on contemporary theatrical productions. Interview filmed by Doctor Miranda on May 28th, 2015, in Florianópolis, Santa Catarina State, Brazil.

Keywords: Greek theatre; tragic heroines; gender; Electra; Nelson Rodrigues

ISSN: 1414.5731

E-ISSN: 2358.6958

\footnotetext{
${ }^{1}$ Doutora em Estudos Clássicos pela University of London, Helenista com pesquisas no campo da Literatura Grega Clássica e sua recepção no mundo atual. Autora do livro Electra Ancient and Modern: Aspects of the Tragic Heroine's Reception (2011), editora de Dialogues with the Past: Classical Reception Theory and Practice (2013), e co-editora das obras War as Spectacle: Ancient and Modern Perspectives on the Display of Armed Conflict (2015, com V. M. Hope) e Locating Classical Reception on Screen: Masks, Echoes, Shadows (2018, com R. Apostol). No momento, Bakogianni dedica-se a escrita de um livro sobre a heroína trágica Antígona e leciona na área de Estudos Clássicos na Massey University, Nova Zelândia. http://www.massey.ac.nz/massey/expertise/profile.cfm?stref=111450

${ }^{2}$ Professora Dra. Associada. Departamento de Artes Cênicas e Programa, de Pós-Graduação em Teatro. Universidade do Estado de Santa Catarina (UDESC). brigidaudesc@gmail.com

${ }^{3}$ Bolsista de Iniciação Científica (CAPES), vinculado a pesquisa A Terceira Onda: Graduando de Licenciatura em Teatro pela Universidade do Estado de Santa Catarina, ator, produtor cultural e pesquisador da temática teatro-gênero-sexualidade.

${ }^{4}$ Para saber mais sobre a produção, visite o site https://stonecrabs.co.uk/our-lady-of-the-drowned/
} 


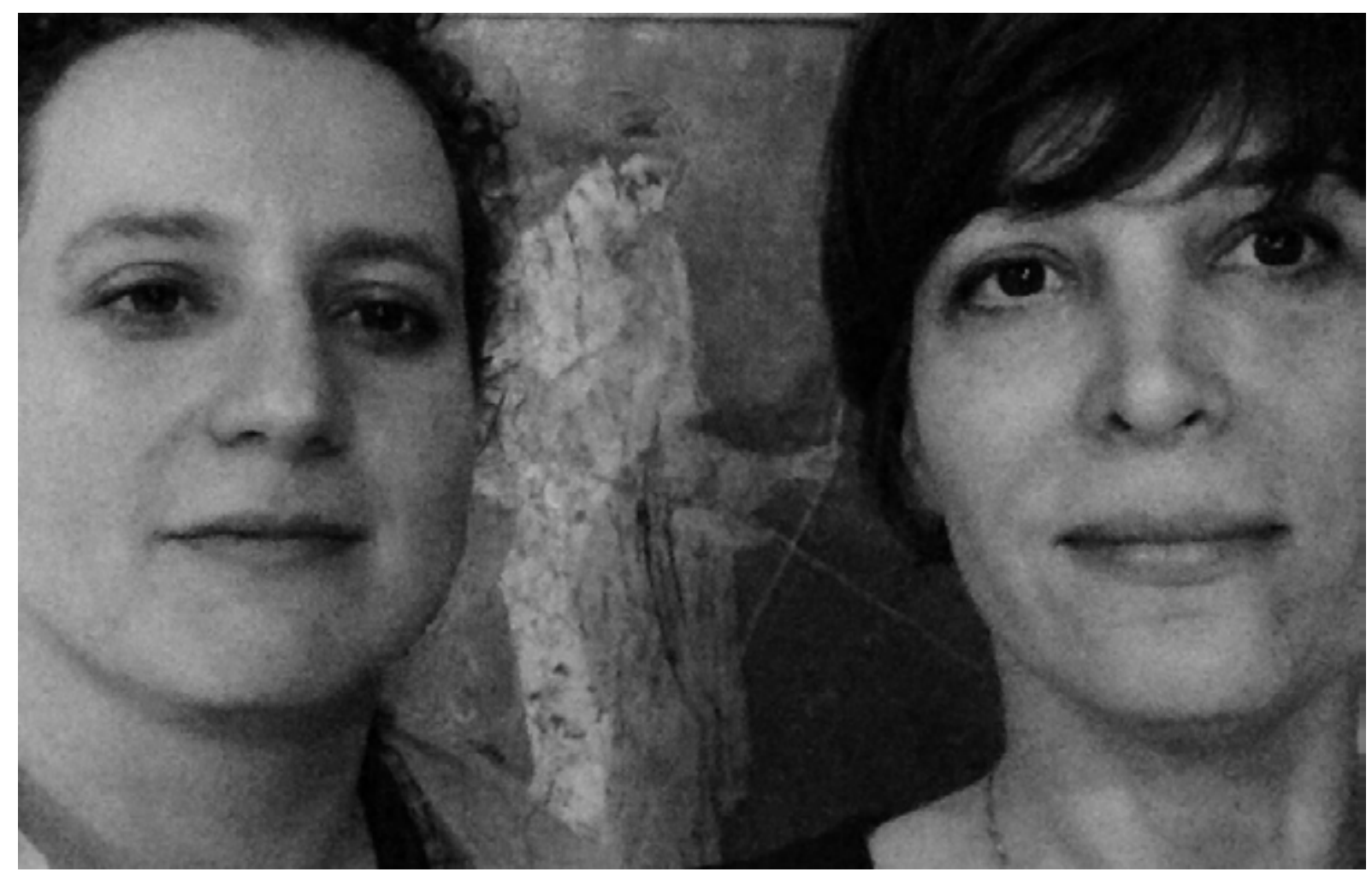

Anastasia Bakogianni e Maria Brígida de Miranda

Self na casa de Brígida Miranda, no dia da entrevista, em 28 maio 2015.

No ano de 2015, a pesquisadora ateniense do Institute of Classical Studies, Reino Unido, e especialista em recepção da literatura dramática da Antiguidade Grega na cultura contemporânea Dra. Anastasia Bakogianni visitou o Brasil a fim de participar de uma série de atividades de pesquisa ligadas a um de seus temas favoritos, qual seja: as heroínas trágicas e as ressonâncias da mitologia e do drama gregos no teatro brasileiro ${ }^{5}$.

A convite do Programa de Pós-graduação em Teatro ${ }^{6}$, Bakogianni proferiu a palestra intitulada "Electra vai para o lado escuro: Nelson Rodrigues e a reconfiguração da heroína trágica em Senhora dos Afogados"7, na manhã de 28 de maio de 2015, no Auditório do Departamento de Música, para uma plateia de interessadas/os. Ao fazer a tradução simultânea, me deparei com a riqueza de um campo - os Estudos Clássicos, que são, de certa maneira, um dos berços dos estudos de teatro nas universidades brasileiras. Contudo, tive a intuição de que nós, pesquisadoras e pesquisadores das artes da cena, pouco notamos como esse campo passa por contínuas transformações.

\footnotetext{
${ }^{5}$ A pesquisadora visitou o Brasil, como palestrante convidada, no II Congresso Brasileiro de Retórica (http://www.letras.ufmg.br/retorica2), em 2012, e no XI Seminário Archai: Deuses, Homens e Heróis - entre Gregos e Baianos (http://www.letras.ufmg.br/ArchaiXI/), em 2013, ambos na UFMG. Em 2015, a Dra. Bakogianni foi pesquisadora visitante na UFMG, a convite da pesquisadora e professora Dra. Maria Cecilia de Miranda Nogueira Coelho (Departamento de Filosofia -- UFMG) com apoio da Fapemig, em projeto do Programa de Pós-graduação em Filosofia, quando proferiu primeiro a palestra "Electra vai para o lado escuro: Nelson Rodrigues e A reconfiguração da heroína trágica em Senhora dos Afogados" na UFMG. A palestra foi organizada pela área de Estudos de Recepção do programa, na Linha de Pesquisa "Filosofia Antiga", e pelo Núcleo de Estudos Antigos e Medievais (Neam) da Fale e da Fafich. Agradeço a parceria com a professora da UFMG Dra. Nogueira Coelho, que me colocou em contato com a Dra. Bakogianni e nos apoiou nos trâmites da viagem. Para saber mais, acesse: https://www. ufmg.br/online/arquivos/038394.shtml

${ }^{6}$ Nesta época, eu era subcoordenadora do Programa de Pós-graduação em Teatro (PPGT/UDESC) e propus à minha colega coordenadora, Dra. Fátima Costa de Lima, que convidássemos a Dra. Bakogianni para estender a sua viagem de Belo Horizonte até Florianópolis e ministrar uma palestra direcionada às alunas e aos alunos da pós-graduação do PPGT. Nossa verba era pequena, mas conseguimos pagar as passagens nacionais, e Bakogianni generosamente concordou em proferir a palestra sem custos de pró-labore e em ficar hospedada na minha casa, na Lagoa da Conceição, em Florianópolis.
}

${ }^{7}$ Para saber mais sobre o evento, acesse a página de divulgação do Núcleo de Comunicação do CEART/UDESC do dia 27/05/2015: https://www.udesc.br/noticia/ udesc_recebe_convidada_internacional_para_palestra_sobre_pe\%c3\%a7a_de_nelson_rodrigues_nesta_quinta 
Valeria a pena nos perguntarmos em que medida os currículos dos cursos de teatro apresentam discursos sobre a história, a dramaturgia e as práticas cênicas do "teatro grego" amparados em reflexões dos séculos XIX e XX?

Esta entrevista me foi concedida na tarde de 28 de maio de 2015. Neste dia, nos sentamos na sala de minha casa para tomar um chá e pensarmos em como faríamos a entrevista. Decidimos que ela seria filmada e que depois eu a transcreveria. Liguei a câmera de meu Ipad e conversamos por uma hora. Foram ao todo sete clip de filmes, que eu imaginava poder em breve transcrever e publicar. Ledo engano. Hoje, três anos depois, com a ajuda de Arthur Gomes, bolsista de Iniciação Científica do meu Projeto de Pesquisa "A Terceira Onda: Práticas Teatrais Feministas no Brasil Contemporâneo", revi as filmagens que fiz de Bakogianni naquela tarde de inverno. Senti nesse momento que era um presente que eu havia ganhado, mas que por causa de outras demandas de trabalho eu havia deixado guardado, à espera de um tempo, um tempo para olhar e perceber novamente seus significados. Uma mulher ateniense discursa...Vejo seu perfil delineado pela luz do entardecer e escuto novamente suas palavras, ecos de uma Grécia pouco conhecida... talvez mais feminina e mais dionisíaca. Ou seria apenas a nossa invenção de um outro passado?

\section{Eu gostaria que você me falasse um pouco desta área de interesse de pesqui-} sadoras e pesquisadores dos Estudos Clássicos, especializados em tragédias gregas, cujo foco é a análise de peças contemporâneas, especialmente de peças de Nelson Rodrigues, como "Nossa Senhora dos Afogados".

Obviamente, da perspectiva de uma classicista, eu estou sempre buscando por ecos, ecos clássicos, mais especificamente da literatura grega, em trabalhos modernos. Algumas vezes é fácil fazer essa conexão, porque o próprio autor indica que ele a está fazendo no trabalho de teatro. Como no caso de Eugene O'Neill, quando ele trabalhou baseando-se na trilogia Oresteia, de Ésquilo, e transformou-a em uma versão americana dessa trilogia. Então ele trouxe a ação dessa peça para situá-la nos Estados Unidos da América e criou uma nova versão, isto é, uma nova história baseada numa história antiga. E chamou a sua peça de Mourning Becomes Electra [traduzida para o português como "Electra Enlutada" ou "Electra Fica Bem de Luto"]. Imediatamente, nesse caso, ele está nos sinalizando que está se engajando, se envolvendo em uma ação de apropriação. Mas no caso de Nelson Rodrigues, de sua peça Nossa Senhora dos Afogados, a sua ação não é tão aberta. Não é tão direta quanto a de O'Neill. Estamos lidando, então, com uma recepção mascarada ou indireta do drama grego que é mediado pelo texto de O'Neill. Além disso, porque eu acho que Nelson Rodrigues estava pensando em termos mais gerais sobre o mito de Electra. Ou seja, ele não estava pretendendo fazer uma adaptação do mito, mas criando o seu próprio trabalho, a sua própria peça. E eu acho que ele lida com estes arquétipos mitológicos encontrados na história de Electra, como o caso da filha que faz parte de um matricídio para apoiar a voz do pai. Então, ela renega completamente a mãe em favor do pai. Esse é um elemento que eu acho que Nelson Rodrigues pega da história. E essa ideia é mediada pela ciência da psicanálise de Freud e Jung. 
Então, há uma conversa acontecendo, contudo, não é apenas entre dois textos $A$ e $B$, mas, na verdade, uma conversa entre muitos textos e uma conversa entre muitas histórias de recepções - e eu digo recepções no plural.

\section{O que mudou dos Estudos Clássicos em termos de abordagens do teatro grego do século $V$ a. C. para investigações feitas no século $X I X$, depois no $X X$ e hoje no XXI?}

Eu acho que houve, na verdade, uma mudança bastante radical de como as tragédias gregas eram percebidas no século XIX para como elas foram vistas no XX e, é claro, como agora o são no XXI. No primeiro, houve um renascimento do interesse pelos clássicos. Por exemplo, houve uma produção da peça "Antígona", na Alemanha, que foi muito popular. Mas o experimento não foi repetido - foi uma dessas histórias de sucesso que acontece apenas uma vez! Apesar de ter sido um sucesso, ela não estimulou uma nova tendência. As tragédias gregas também começaram a ser encenadas dentro das universidades. Inclusive a serem encenadas em grego antigo e seguindo os textos originais. E essa foi uma tradição em universidades, como Cambridge, Oxford, Brymore e outras, como nas faculdades [colleges ${ }^{8}$ ] norte-americanas. Então, o que é interessante é que as mulheres também fizeram parte dessas encenações, que algumas vezes eram feitas nas faculdades de mulheres - nesses casos eram produções inteiramente femininas. Isso não acontecia na Inglaterra, onde as mulheres eram completamente excluídas das faculdades; isso acontecia particularmente nos EUA - o caso de mulheres encenando peças gregas.

A maneira como essas peças eram encenadas não é o que nós consideramos como exatamente teatrais; as pessoas eram muito preocupadas com questões de autenticidade dos figurinos, cenários, objetos de cena; elas queriam que fossem tão autênticos como teria sido na Grécia Antiga, mas essas peças eram majoritariamente encenadas por estudantes da área de Literatura Grega, ou seja, essas pessoas não eram treinadas como atores, e mesmo em produções profissionais, as peças eram encenadas de forma muito declamatória. Os atores se sentavam lá e declamavam, e as encenações não eram muito teatrais. Isso é o que nós chamamos de um estilo arqueológico de encenação. Quer dizer, não tiravam partido do que realmente o teatro enquanto mídia poderia oferecer; no entanto se tratava de textos que eram feitos para serem encenados no teatro. Essa foi uma fase interessante; isso começou a mudar no início do século XX. As pessoas tornaram-se mais corajosas na maneira de encenar as peças gregas; começaram a transformar as peças, tratar de assuntos mais relevantes, principalmente em relação ao que estava acontecendo no momento em que elas estavam sendo encenadas. Por exemplo, Gilbert Murray traduzia peças gregas e foi instrumental na encenação dessas peças nos palcos londrinos. Parte da sua motivação era protestar, por exemplo, contra o envolvimento do Império Britânico na condução de várias guerras coloniais. Então começou essa tendência de uma apropriação muito liberal das tragédias gregas, em particular para protestar contra a

\footnotetext{
${ }^{8}$ Optamos por manter a palavra em inglês college, que nessa língua pode significar tanto "escola" como "colégio", como "faculdade" ou "universidade". Entendemos que na entrevista ela se refere aos colleges de forma específica, ou seja, como ensino superior.
} 
guerra e contra a inequidade de gênero. Sendo assim, algo novo começou a acontecer. Começaram a querer que as peças se tornassem mais atrativas, assim como a criar encenações mais dramáticas, mais teatrais, para que a plateia se tornasse imersa e não desengajada das encenações; não queriam que a peça fosse entediante. Tem algo interessante sobre a primeira produção de Oxford de peças gregas no século XIX, pois foi um grande sucesso e uma novidade, mas também as pessoas logo perderam interesse. Basicamente o que estavam fazendo não era um bom teatro. No século $X X$, os encenadores começaram a mudar isso; iniciaram uma tendência que continua até hoje, pois passaram a ter menos reverência ao teatro grego, assumiram maior liberdade, maiores riscos, experimentaram diferentes maneiras de encenar peças gregas, colocaram os atores em figurinos modernos, transplantaram as peças gregas para outros contextos. Existiram peças muito fantásticas do drama grego feitas na África, por exemplo, transportando essas peças para um contexto africano contemporâneo e também, claro, encontramos adaptações de tragédias gregas por dramaturgos africanos (eu estou pensando especificamente em The Island [A Ilha], uma peça sobre prisioneiros que estão montando a peça Antígona). "Antígona" é agora frequentemente encenada como uma peça que se opõe à tirania, basicamente, porque a protagonista feminina se levanta e se opõe ao tirano Creonte. Ela enterra o seu irmão a despeito da lei imposta por Creonte, porque acredita que essa é a coisa certa a se fazer, pois os deuses estão apoiando o rumo dessa ação. Creonte tenta evitar, prevenir ou impedir o enterro do irmão dela; há um desenvolvimento muito interessante nesse sentido, como na maneira como o drama grego é visto ou como ele é encenado no mundo moderno.

\section{A que você atribui esse interesse contemporâneo pela encenação de peças} gregas? Seria uma nova fase ou uma ressurreição das tragédias gregas no século XXI?

Acho sua pergunta muito interessante. Eu acredito que é um pouco de um renascimento das tragédias gregas no teatro de língua anglófona, mas isso parece acontecer em ciclos. De novo é interessante. A impressão é a de que, quando existe guerra ou todo o tipo de crise, as tragédias gregas parecem se tornar muito populares novamente nesses tempos; talvez exista uma conexão nessas duas coisas, porque no século $V$ a.C., quando as tragédias gregas surgiram como gênero, era um tempo de crise, de guerra, Os Persas atacaram a Grécia, e as cidades-estados conseguiram afastá-los, mas de novo as cidades-estados começaram conflitos entre elas. Atenas estava numa constante condição de guerra durante esse período de florescimento das artes. Parece haver uma conexão nesse momento moderno, entre tempos difíceis de guerra e tragédias gregas. Talvez porque o teatro grego levante uma série de perguntas difíceis e normalmente não ofereça respostas; então é uma forma intrinsecamente democrática de teatro que faz uma série de perguntas difíceis, por exemplo, o que você faz quando sua mãe mata seu pai? Como você responde a isso? O que você faz? Esse é o dilema que Electra encara... ou Antígona: o que ela faz quando é negado a um de seus dois irmãos o direito de ser enterrado? Essas são perguntas muito difíceis. E tem também a famosa situação de Édipo: sem saber, ele dorme com sua própria mãe e, quando descobre a verdade, como ele responde a isso? Então a 
tragédia grega lida com dilemas trágicos, difíceis e duros. Quem sabe isso explique esse tipo de conexão em tempos nos quais as pessoas estão se fazendo perguntas muito difíceis; às vezes eu acho que é bem mais fácil pensar e refletir sobre essas perguntas difíceis pelo veículo dessas tragédias gregas: é muito distante, muito velha, antiga; é distante de nós. É muito mais fácil lidar com isso no palco do que lidar com isso nas nossas próprias vidas particulares, privadas e com assuntos contemporâneos. Então, por exemplo, a peça As Troianas trata da situação do pós-guerra, ou seja, o que acontece depois do conflito. Essa peça é constantemente usada hoje para refletir sobre as consequências da guerra. Ela foi particularmente popular durante as guerras do Irã e do Afeganistão, pois as pessoas começaram a questionar o que estava acontecendo; assim ela se tornou um meio de problematizar o que acontece na guerra e especialmente de mostrar como as mulheres podem se tornar muito cruéis com sobreviventes do lado que perde a guerra, porque obviamente os gregos massacraram todos os homens troianos, escravizaram as mulheres e as crianças troianas e, em alguns casos, até mesmo mataram as crianças. Por exemplo, Astíanax, o príncipe de Troia, tem que morrer, é claro; os gregos estão com medo dele; o pai dele, Heitor, era um grande herói. Eles têm medo que esse príncipe cresça e quando mais velho queira vingar seu pai pelo que aconteceu em Troia e pelo que aconteceu com sua família. Por essa razão eles matam o menino; então é uma peça que costuma levar em conta uma série de questões sobre a guerra no geral: o comportamento dos vitoriosos.

Sei que sua área favorita de pesquisa são as heroínas trágicas. Gostaria de saber o porquê de seu interesse por elas, uma vez que existem tantos heróis trágicos. Como você explica a sua predileção pelas personagens Electra e Medéia? Existem diferenças de perfil entre a heroína e o herói trágico? Qual é a diferença, se existe, entre a construção do perfil da heroína trágica e do herói trágico no drama grego clássico?

Para ser sincera, acho que minha escolha se relaciona primeiramente ao fato de eu ser uma mulher. Em segundo lugar, eu me interesso por questões de gênero, principalmente por aquelas relacionadas a como as mulheres são retratadas no palco. Mesmo considerando que no caso do drama grego as personagens femininas são representadas por homens - o elenco era todo masculino; eram homens fingindo ser mulheres, o que por si só é um tópico interessante. Mas no caso das heroínas trágicas, existe algo distinto sobre elas: o próprio fato de você ter uma personagem feminina exposta a uma plateia masculina já é por si só transgressor, uma vez que as mulheres para os atenienses endinheirados existiam para serem confinadas no Oikos, que em grego quer dizer "casa". O ideal ateniense era este: as mulheres dos cidadãos ricos deviam viver confinadas no lar. Assim, sendo um cidadão rico, você manteria sua esposa presa dentro de casa. Então poderíamos imaginar a presença de uma personagem feminina no palco como algo bastante transgressor. Eu imagino que para uma plateia arcaica isso poderia ser até um pouco chocante. Este é um dos motivos pelos quais o dramaturgo Eurípedes era famoso na Antiguidade: pela sua construção de personagens femininas como Medéia, Clitemnestra, Electra. Ele parecia ter muito interesse pela representação de mulheres no palco. 
Talvez a razão de sua popularidade nos dias de hoje seja porque suas peças podem ser usadas para discutir questões de gênero. E são atualmente questões difíceis. Contudo, é curioso observar que apesar de as peças dele terem sido escolhidas para ser encenadas [na Grécia Antiga], ele raramente ganhava algum prêmio... o que eu acho interessante! Talvez porque ele era um grande inovador - ele alargou as fronteiras do drama grego naquela época e ampliou os limites do gênero trágico. Então, eu, dentre os três dramaturgos gregos conhecidos - Eurípedes, Ésquilo e Sófocles -, sou especialmente fã do primeiro, porque ele retrata muitas heroínas trágicas. Mas a gente sabe que a tragédia grega em si é cheia de heroínas trágicas; e normalmente as más são as que eu acho as mais legais! Por exemplo, há uma peça chamada Alceste, que retrata o martírio de uma esposa que sacrifica a própria vida para que o marido possa viver. Então essa seria uma "boa mulher grega". Mas eu acho as heroínas transgressoras, como Medéia e Electra, muito mais interessantes, e isso, é claro, é um sinal da nossa visão moderna das peças. Porque nesse momento estamos muito interessados em questões de gênero, preferimos muito mais as heroínas perigosas do que as personagens boas, como em Alceste - inclusive essa é uma peça que é raramente montada hoje em dia, enquanto Medéia é posterior, escrita bem depois. Na época em que Medéia foi apresentada pela primeira vez, os juízes estavam bem preocupados com o conteúdo da peça - com esse conteúdo em que Medéia mata os próprios filhos. Essa é uma versão que nós acreditamos que Eurípedes inventou. Então, eu acho que essas peças abrem tantas possibilidades, têm tanto mais do que nós podemos fazer com essas personagens femininas, porque elas quebram barreiras e nos colocam a pensar sobre a posição da mulher na Grécia Antiga ou na Antiguidade. Também é óbvio que nos fazem pensar na posição da mulher hoje em dia e na própria posição dos Estudos Clássicos. Porque até pouco tempo essa área de pesquisa era dominada por homens e agora nós temos muitas mulheres se debruçando, especialmente em tragédia grega. Então eu acho que existe uma mudança muito interessante à medida que nossa área de estudos se desenvolve... e acho que tudo isso é muito bom.

Você disse que Eurípedes inovou ao colocar Medéia deliberadamente assassinando os próprios filhos. Eu gostaria de saber sobre as outras versões: ela mata os próprios filhos ou isso é algo que o mito não traz?

Há muitas versões do mito. Em uma delas, as crianças são mortas acidentalmente por Medéia; em outra, a população enfurecida mata as crianças por vingança, por Medéia ter matado o rei e sua filha. Até onde nós sabemos, Eurípedes escolheu retratar Medéia deliberadamente matando as próprias crianças, o que em si já é muito dramático. O que coloca para a atriz hoje em dia e para o ator naquela época, representando a personagem Medéia, uma grande chance de atuação. É uma grande oportunidade representar uma personagem tão complexa. Eu acho que isso, em parte, é um dos motivos pelos quais as atrizes amam os dramas gregos: porque são grandes oportunidades para as mulheres. Então, voltando à Medéia, ela dá oportunidade à atriz de apresentar essa situação de uma pessoa que está constantemente mudando de ideia, está sempre oscilando entre o que fazer: ela deve manter seus filhos ou não 
cometer o assassinato? Tem esse cabo de guerra entre os sentimentos maternais e o desejo de se vingar de Jasão por ele ter quebrado um juramento. O problema da vingança de Medéia é que Jasão quebrou uma promessa feita a ela. Ele jurou em nome dos deuses. Na Antiguidade, a quebra de um juramento feito aos deuses é uma ofensa muito grave. Além de ele ter quebrado um juramento feito aos deuses, ele vai se casar com uma esposa jovem, mesmo considerando que Medéia já tenha lhe dado dois filhos: esse é um dilema muito trágico. A peça não foi muito prestigiada na época, mas se tornou muito popular no presente; então é interessante observar quais peças das tragédias gregas as pessoas escolhem hoje em dia para encenar. Ao que tudo indica, as peças que retratam mulheres são as favoritas para serem encenadas atualmente, e isso em si parece muito interessante.

Você mencionou na sua palestra que na peça de Eugene O'Neill, Mourning Becomes Electra, ele substitui a ideia de força divina, o destino pela pulsão psicológica. O que eu queria saber é se as representações contemporâneas de Electra também fazem esse tipo de substituição da força divina por outras forças.

Acho que a questão da força divina é particularmente interessante no drama antigo. No pensamento religioso antigo, os deuses não eram uma força amorosa ou de proteção, mas sim muito instáveis e cruéis, e, em última instância, poderiam destruir sua vida. Algumas vezes, os deuses decidiam te apoiar e em outras, não te apoiar. Há um exemplo famoso em llíada de Homero: os troianos e as troianas estão orando à Atena. Heitor também está desesperado rezando à Atena, para que ela os ajude a combater os gregos que estão num cerco sitiando a cidade, mas a deusa decide virar as costas para os troianos, ignorando todas as oferendas que eles estão fazendo, porque ela apoia os gregos e ponto. Então ela não vai escutar os troianos. Mas algumas vezes os deuses mudam de opinião e depois que Troia é derrotada, Atena fica muito brava que os gregos, à medida que invadiam Troia, invadiam e a desafiavam em seus templos. Os gregos mataram pessoas nos altares de Atena, o que foi uma grande ofensa aos deuses, porque as pessoas, quando buscavam abrigo nos templos em uma guerra, esperavam por uma proteção, não podendo haver matança dentro desses espaços. E os gregos quebram essa regra. Atena se torna muito raivosa com eles, exigindo que sejam punidos. É dessa maneira que As Troianas começa tomando por base a conversa entre a deusa Atena e o deus Poseidon, que sempre apoiou os troianos. No início da peça, ele se pergunta: "Por que Atena, que sempre apoiou os gregos, se virou contra eles? Por que ela quer puni-los?" Ela explica que eles se comportaram mal; eles quebraram a regra de não matar dentro dos templos dos deuses e agora ela quer que eles sofram, que eles tenham uma viagem muito perigosa de retorno à Grécia. Eles terão que cruzar os mares, que são de domínio do deus Poseidon. Ela dá autorização a ele para fazer com que eles tenham uma viagem de retorno difícil. $O$ que é interessante é que em muitas encenações modernas a que eu assisti, essa cena é cortada. As encenações começam com a cena das mulheres troianas, e esse prólogo da conversa divina se torna ausente. Eu tenho conversado com vários diretores sobre esse corte, sobre o porquê de eles fazerem esse corte nessa cena, que para os pesquisadores de Estudos Clássicos é bastante importante. 
E é significativo, porque ele mostra que os gregos estão se comportando de uma maneira cruel em relação aos troianos; porém eles também terão uma punição merecida pela maneira como se comportaram em relação aos deuses. Mesmo que os deuses não ajudem os troianos naquele momento, paira a ideia de uma justiça divina na peça. Se você corta essa cena, é claro que essa noção desaparece. Assim você acaba tendo uma visão muito diferente da ação da peça. O que a maioria das diretoras e dos diretores costuma dizer é que "eles/elas não acreditam que uma plateia moderna concorde com essas ideias da Antiguidade sobre os deuses e sobre seus comportamentos". Desse modo, é muito mais fácil cortar essas cenas, deixá-las de fora. Eles/elas podem até deixar algumas referências aos deuses na peça, mas porque os deuses não são representados no palco é muito fácil você subestimar o poder do divino na tragédia grega. Ignorar o divino é algo muito difícil de se fazer em peças como As Bacantes, posto que, nesta, o próprio deus Dioníso - o deus do teatro - desce ao palco... e é uma peça que é muito popular hoje em dia. Eu já vi várias encenações dela; então acredito que essa é uma contradição interessante, mas o que eu acho mesmo é que o apelo dessa peça é você pensar sobre o que é o próprio teatro - é uma peça muito metateatral. De alguma maneira é fácil compreendê-la nesse universo panteísta de múltiplos deuses.

O protagonista se recusa a reconhecer a força de um dos deuses e obviamente isso é uma coisa muito ruim de acontecer, porque os deuses fazem retaliações! $E$ é algo muito esperado que ele a faça de forma muito cruel. O protagonista vai ser morto com seu corpo sendo despedaçado pela sua própria mãe e suas seguidoras; elas estão nesse momento envoltas por um frenesi de mênades dionisíacas. Elas pensam que ele é um leão, e isso também é terrível para Agave - posto que ela mata o próprio filho e fica completamente horrorizada. Então, ao negar a força de um deus, você traz para você essa punição terrível, talvez porque seja um pouco mais fácil de entender esse tipo de relação. Essa é uma peça na qual o divino é muito mais presente. Contudo, quando a gente se volta para a peça Electra - eu recentemente assisti a uma produção no Old Vic Theatre, em Londres, com Kristin Scott Thomas no papel de Electra ${ }^{9}$-, pelo menos algumas das referências são feitas em relação aos deuses e outras cenas são ritualísticas. Em uma das cenas, Clitemnestra queima oferendas para o fantasma de Agamémnon, como uma forma de agradá-lo depois que ela o mata - eu não acho que isso vai funcionar, mas pelo menos ela tentou! (risos) Nessa montagem, há cenas que sugerem não a religião em si, mas o ritual. Eu acho que é esse tipo de abordagem das tragédias gregas que trabalham com rituais que os/as diretores/as modernos/as ainda adotam.

Outra maneira de abordar as tragédias gregas é a explicação psicológica das peças, como, por exemplo, "Édipo". O complexo de Édipo, criado por Freud, se tornou tão famoso, que formata não apenas a maneira de perceber a peça de Ésquilo, mas também outras peças no canon teatral. Por exemplo, a gente não consegue ver Hamlet sem pensar naquele complexo edipiano e na versão freudiana do mito de Édipo. Eu já assisti a uma montagem de Hamlet em que Hamlet está rolando na cama

${ }_{9}^{9}$ Para saber mais sobre a produção com a atriz Scott Thomas, acesse: https://www.telegraph.co.uk/culture/theatre/11138712/Electra-Old-Vic-theatre-at-its-best. html 
com a mãe dele; então é uma metáfora visual óbvia do desejo edipiano pela mãe. Aí eu parei e fiquei pensando... era isso mesmo que Shakespeare queria mostrar? Ou será que somos nós projetando isso nas peças do passado? Às vezes eu acho que isso também se aplica nas tragédias gregas. Será que é por sermos tão influenciados pela área de estudos da cena, por esses ideais freudianos, como, por exemplo, o complexo edipiano - o desejo de Édipo por sua mãe -, que interpretamos as peças antigas dessa maneira? Por outro lado, na peça de Sófocles, fica muito claro que Édipo não sabe que ela [Jocasta] é sua mãe, e este é o ponto principal: ele não sabe que a rainha não é mãe dele, ele não sabe a verdade; não é que ele deseje conscientemente sua mãe; é na verdade um destino terrível que ele tem. Também eu acredito que, no caso da peça Electra, a personagem se sente mais filha do pai do que da mãe dela. No pensamento antigo, havia essa ideia de que as crianças são mais filhas do homem do que da mulher; as mulheres eram vistas como um vaso que carregava as crianças, enquanto os homens eram os elementos ativos da procriação. Então essa é a visão que aparece no julgamento de Orestes, que é a conclusão da trilogia, quando Apolo defende as ações de Orestes: vejam só, o que importa é que a mulher não é ativa na criação dos filhos; quem cria os filhos é o homem, portanto, não há problema em se matar a mãe. O mais importante nesse crime é que a mãe assassinou o pai. É importante que as pessoas estejam conscientes tanto desse pensamento antigo quanto do contexto do pensamento moderno. Caso contrário, fica muito fácil montar uma peça só do pensamento moderno e se esquecer do que acontecia no pensamento da Antiguidade, mas obviamente quando você está pensando em encenar uma peça, isso se torna menos importante, mas do ponto de vista de um classicista, é interessante observar o que diretores e diretoras modernas mantêm ou decidem cortar, ou ainda minimizar. Isso diz muito sobre nós, sobre nossa relação com as peças gregas. Então eu acho que existe uma dinâmica, uma conversa muito interessante acontecendo aí.

\section{Eu gostaria que você falasse de que maneira a peça Nossa Senhora dos Afoga- dos, de Nelson Rodrigues, usa a tragédia grega Electra como ponto de partida para criar uma estrutura completamente nova.}

Como eu disse antes: essa conversa entre o mito antigo de Electra e as peças dramáticas é muito interessante, porque ela é uma conversa escondida, mascarada; não é óbvia a primeira vez que você assiste à peça Nossa Senhora dos Afogados. Ela tem um subtexto de Electra, e de fato a primeira vez que eu apresentei esse artigo sobre Nossa Senhora dos Afogados, recebi um comentário muito interessante numa conferência em Londres, em 2014, e isso veio de um brasileiro que estava na plateia: "nossa, eu nunca percebi que essa peça era uma recepção de "Electra", e eu conheço essa peça muito bem". Aí eu pensei: "ah! olha só que interessante!" Isso para mim é uma pergunta bem importante para refletir sobre a teoria da recepção, uma teoria que pede a nós que nos perguntemos e que sejamos bastante autorreflexivos sobre o que nós estamos fazendo como estudiosos. Assim, aquela pergunta me colocou imediatamente a pensar: será que sou eu, por ser uma classicista, que estou vendo "Electra" nessa peça? Será que sou eu que estou vendo "Electra" em todos os lugares?... Eu tenho interesse em Electra, e ela foi o objeto de minha tese de doutorado. Assim, eu 
comecei a ler textos de estudiosos brasileiros sobre as peças de Nelson Rodrigues, e alguém já tinha apontado essa ligação entre as peças dele e a trilogia de Ésquilo, chamada Oresteia. Então não era só eu pensando nisso; existem outras pessoas que estão vendo essas ligações e apontando essas conexões. O próprio Nelson Rodrigues afirmou que ele devia à peça de Eugene O’Neill, Mourning Becomes Electra. Logo, isso para teoria da recepção é uma afirmação muito direta da relação com a trilogia de Ésquilo. As ligações estão lá, mas elas não são tão diretas, tipo A para B; é uma conexão que é circular. Você poderia argumentar que há ecos na minha própria visão; se você reconhece isso, pode dizer que Nelson Rodrigues se apropriou de alguns elementos das tragédias gregas, e isso não diminui o valor das peças dele. $O$ que está se fazendo é mostrando que ele tem um diálogo maior com uma tradição mais ampla, tanto a peça norte-americana como as peças antigas gregas, ou seja, isso só atribui mais camadas às peças de Nelson Rodrigues, tornando-as mais interessantes como peças brasileiras. E nós sabemos que elas são muito brasileiras: as histórias se passam no Rio de Janeiro, apresentam personagens brasileiros, o que denota, a meu ver, que ele pegou o que ele queria para suas peças e incorporou outras coisas de alguma maneira. Mas as conexões não são óbvias; isso é o que a gente chama na teoria da recepção de um novo trabalho; isso não é uma adaptação; isso não é nem mesmo uma apropriação; é uma coisa completamente nova; é o que eu chamo de incorporação. A gente tem uma percepção de que a Grécia Antiga é o berço da civilização ocidental; então se valendo dessa suposição de que ela seja um lugar de origem, Nelson Rodrigues escolheu deliberadamente tomar pontos emprestados dessa tradição, e também de Eugene O'Neill.

Rodrigues está se engajando tanto com a tradição dos textos antigos como com a trilogia de O'Neill. Ele toma emprestado elementos de todas essas fontes e as redesenha para criar uma peça claramente brasileira. Nós estamos ainda trabalhando nisso na área de teoria da recepção: estamos tentando entender isso e essas contradições, particularmente onde não é óbvio, onde a recepção não é óbvia. A gente ainda está tentando compreender como que essas conexões acontecem em lugares onde não é óbvio, onde a recepção não é óbvia. Você poderia, inclusive, argumentar que a Nossa Senhora dos Afogados não é uma peça de recepção dos elementos gregos, e essa é uma opinião absolutamente válida. É por isso que eu digo que eu estou abordando a peça segundo a perspectiva de uma classicista. Ou seja, estou ativamente buscando essas conexões. Mas obviamente você poderia vê-la de uma perspectiva diferente também.

Bem, eu gostaria de fazer a última pergunta para você. Você é uma mulher, uma mulher grega, uma ateniense, e é também uma classicista vivendo em Londres, e envolvida com toda essa tradição de estudos dos mitos gregos e do drama antigo, e da filosofia. Então, qual é seu sentimento em relação a essa visão mais recorrente e popular da Grécia e do pensamento grego como algo racional, lógico e branco? Eu gostaria que você falasse um pouco dessa relação entre Apolo e Dioníso. A Grécia é, na sua opinião, mais apolínea ou mais dionisíaca?

Eu acho que o que acontecia era um cabo de guerra, uma tensão entre o apolíneo e o dionisíaco, uma visão da Grécia Antiga e da tragédia grega. No século XIX, eu argu- 
mentaria que a visão apolínea venceu. A Grécia Antiga era frequentemente vista como um lugar muito racional, um lugar de branquitude, e era usada como uma justificativa pelo pensamento colonial para a opressão de outros povos. Por exemplo, na Índia, na tentativa de os indianos terem uma educação que os permitisse tornar-se servidores públicos, eles tinham que aceitar essa visão sobre a Grécia. Então, se você quiser, era essa a opinião dominante da maneira como a Grécia Antiga era vista. Mas havia também alguma resistência, mesmo naquela época, a essa visão dominante, hegemônica, que conectava os clássicos ao interesse colonizador. Por exemplo: o que era chamado o "amor grego" - os homossexuais usavam essa ideia do "amor entre homens" - e eles se sentiram atraídos pela literatura grega, que tinha esse tipo de representação, que naquela época era um amor proibido, ou seja, este foi um ramo de pensamento de recepção da Grécia Antiga que ia no sentido contrário ao pensamento dominante. Mas mesmo na Índia havia um pensamento filosófico resistente a essa ideia da Grécia Antiga como o berço da civilização ocidental. Porque essa visão era usada para explicar e reforçar a visão colonial de que os indianos eram povos inferiores à civilização ocidental. Então, Mahatma Gandhi e outros pensadores indianos trabalharam para contrapor esse tipo de visão. À medida que nós avançamos no século XX, eu acho que gradualmente a visão dionisíaca da Grécia Antiga ia assumindo o primeiro plano. Eu acho que você vê esse reflexo nas encenações das tragédias gregas. Como eu mencionei antes: no século XIX, era tudo muito arqueológico e declamatório.... Basicamente não era um bom teatro. Mas ao passo que nós adentramos o século $\mathrm{XX}$, a paixão desmedida dos heróis e das heroínas trágicas toma dianteira novamente e se torna apropriado para os/as encenadores/as expressarem isso no palco. Assim, se antes "Electra" não era realmente popular no teatro, de repente, no século $X X$, nós começamos a ver uma grande quantidade de produções desta peça e muitas adaptações da história em uma variedade de veículos. Hugo von Hofmannsthal tornou-se famoso por criar um libreto que Strauss pegou e encenou - uma maravilhosa "Electra" operística, completamente exagerada e completamente tomada pela ideia de vingança. Então, novamente temos essa ideia de que Electra deseja vingar-se. Isso se torna aceitável e popular novamente no teatro. Portanto, eu acho que isso é indicativo de uma abordagem mais dionisíaca. Ou seja, o lado negro das paixões é novamente retratado, não é mais tão racional. Tem um livro famoso de um acadêmico britânico que salienta o quão irracional são algumas das peças de Eurípedes, como, por exemplo, "As Bacantes", na qual as pessoas perdem a sua sanidade. O que, sem dúvida, contrasta e choca com a visão de que os gregos eram muito racionais!

Se você dá ao drama grego sua expressão completa, você não pode mais sustentar a ideia de que os gregos são completamente racionais. Em termos de raça, os gregos tinham essa ideia de que os outros povos eram bárbaros, que falavam em línguas engraçadas e que se vestiam de forma engraçada. Mas isso também poderia ser aplicado a qualquer um que não fosse grego. Assim, não era tanto uma questão de cor ou do que hoje nós chamamos de etnia. Eu acho que a apropriação da Grécia Antiga pelas ideias políticas de direita é uma apreensão errônea do que aqueles temas significavam na Grécia Antiga. Uma coisa que acho particularmente interessante é que quando os persas atacaram os gregos, eles começaram também uma demonização dos povos do Oriente, ou seja, "o outro". Mas isso foi uma resposta aos invasores 
e talvez isso tenha evoluído ao longo dos séculos em um tipo de orientalismo - o medo do Oriente, o medo do outro. É válido dizer que Heródoto, o historiador da Antiguidade Grega - que escreveu a história das guerras persas -, era muito cuidadoso ao elogiar os persas, os generais persas ou os soldados que se comportavam bem; ele dizia que às vezes os gregos não se comportavam corretamente. Ou seja, novamente, eu penso que algumas vezes, ou melhor, sempre, os clássicos são apropriados por pessoas que desejam um apoio a agendas específicas e com objetivos específicos. Nós todos fazemos isso! E por a Grécia Antiga ser tão conhecida, tem tido uma vida "pós-morte" muito longa e muitas, muitas pessoas a usaram e muitas abusaram dela. Dessa forma, a mesma civilização tem sido apropriada de formas horrendas pelos nazistas, mas ao mesmo tempo ela tem sido usada para protestar contra as guerras modernas, que são vistas como injustas e errôneas. Então, você pode ver que ela pode ser basicamente usada por grupos opostos em seus extremos.

Mas eu acho que é porque a Grécia tem esse tipo de capital cultural, que muita gente já ouviu sobre a Grécia Antiga. Muita gente tem certas ideias sobre a Grécia Antiga, então fica fácil tocar nisso e usar isso para apoiar suas próprias agendas locais, independentemente do que elas sejam. Penso que é uma conversa que ainda está acontecendo; do ponto de vista de uma classicista, é maravilhoso, porque isso me dá muito material para trabalhar! Há tantos estudos de caso interessantes e que nunca irão acabar em termos de materiais a serem produzidos e estudados! Novas coisas estão acontecendo, novas versões das peças, novas produções, novos trabalhos artísticos: nas artes, no cinema, no pensamento político. Assim, a Grécia Antiga e certamente Roma ainda estão conosco e em volta de nós: no imaginário público e nos debates públicos também que estão acontecendo hoje. Embora o século $V$ a.C. esteja tão distante de nós cronologicamente, de alguma forma ele ainda está vivo e ainda é relevante no momento atual. O que é, obviamente, maravilhoso para mim! Mais coisas para eu fazer! (risos)

\section{Muito obrigada por sua generosidade em compartilhar seu conhecimento conosco.}

Anastasia Bakogianni e Maria Brígida de Miranda 


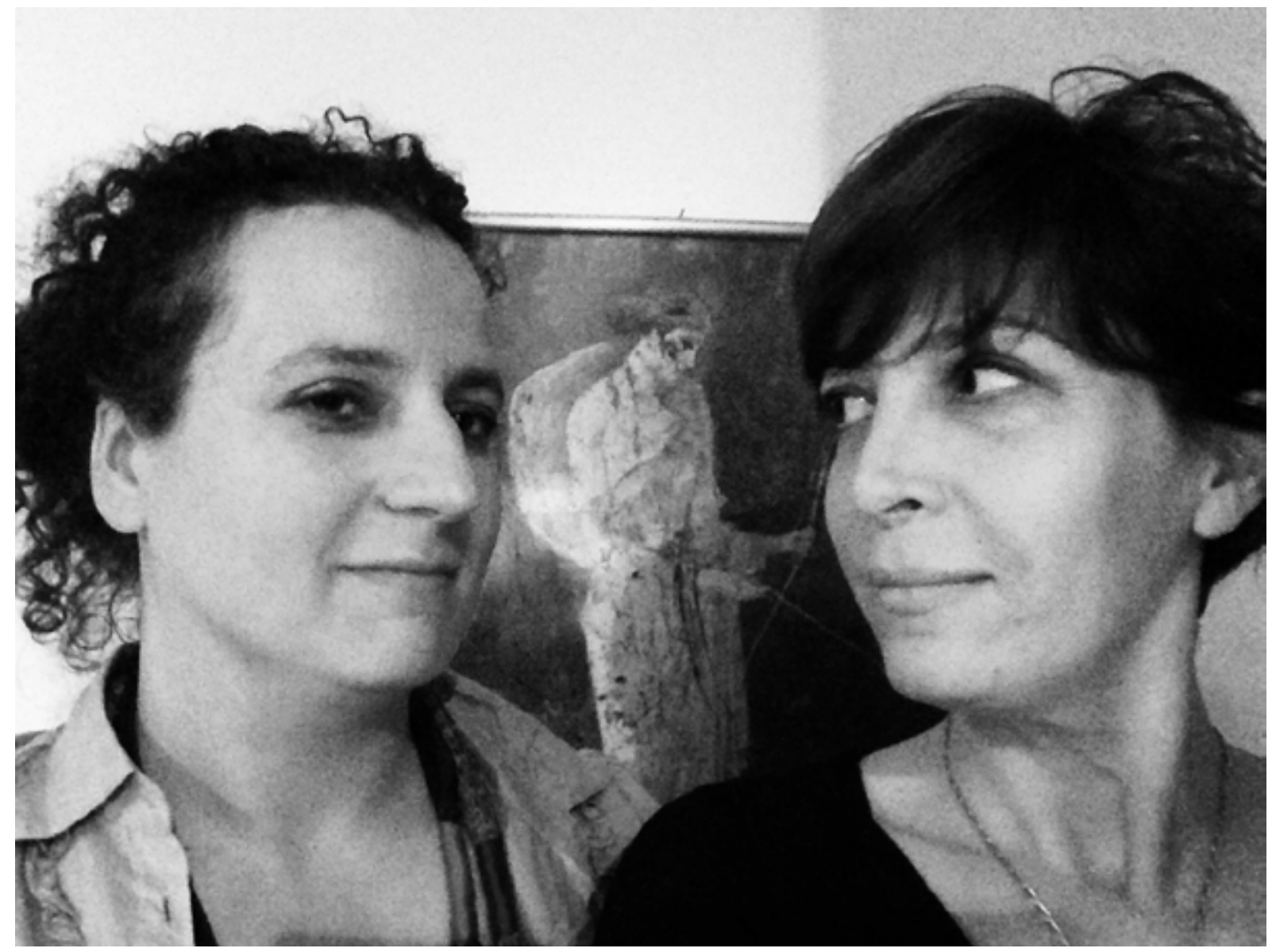

Self na casa de Brígida Miranda, no dia da entrevista, em 28 maio 2015.

Recebido em: 14/10/2018 Aprovado em: 14/10/2018 